\title{
Field surveys of the Vulnerable pygmy slow loris Nycticebus pygmaeus using local knowledge in Mondulkiri Province, Cambodia
}

\author{
Carly Starr, K. A. I. Nekaris, Ulrike Streicher and Luke K. - P. Leung
}

\begin{abstract}
The pygmy slow loris Nycticebus pygmaeus is a little-studied primate endemic to Vietnam, Laos, southern China and eastern Cambodia. Our study aimed to gain local knowledge on the distribution and ecology of, and threats to, the species by interviewing hunters, traders and wildlife protection staff, and to verify this information using a spotlighting survey in three major reserves in Mondulkiri Province, Cambodia. Encounter rates of pygmy loris were assessed along 29 transects $(129.5 \mathrm{~km})$, yielding observations of 26 individuals. Mean encounter rates were $0.40 \mathrm{~km}^{-1}$ in Seima Protection Forest, $0.10 \mathrm{~km}^{-1}$ in Phnom Prich Wildlife Sanctuary and $0.00 \mathrm{~km}^{-1}$ in Mondulkiri Protected Forest. Informants had knowledge of where populations occurred, their diet, sociality and habitat preferences. Widespread large population declines were reported and informants linked this to high hunting pressure, particularly in 2001 and 2002. In late 2008 and 2009 we resurveyed three transects that had high encounter rates in early 2008 and failed to detect any lorises. Local informants reported high hunting pressure during the previous wet season in two of these sites, and a gold mine development was underway in the third site. Urgent actions are required to address these population declines and to assess the conservation status of pygmy lorises throughout eastern Cambodia.
\end{abstract}

Keywords Bunong, Cambodia, hunting, local ecological knowledge, Nycticebus pygmaeus, pygmy slow loris

\section{Introduction}

B iodiversity loss in Asia is occurring at an unprece3 dented rate, and monitoring the abundance and distribution of species is essential for their conservation and for assessments for the IUCN Red List (IUCN, 2010). Such information is lacking for many Indo-Chinese primates, and particularly for nocturnal primates because they are often elusive and are difficult to study during their active periods.

CARLy Starr (Corresponding author) and LuKe K.-P. Leung School of Animal Studies, University of Queensland, 4343, Australia. E-mail: c.starr@uq.edu.au

K.A.I. NeKARIS Nocturnal Primate Research Group, School of Social Sciences and Law, Oxford Brookes University, Oxford, UK

Ulrike Streicher Wildlife Rescue Programme, Nam Theun 2 Hydropower Project, Nakai, Laos

Received 27 August 2009. Revision requested 9 December 2009. Accepted 14 January 2010.
The pygmy slow (hereafter pygmy) loris Nycticebus pygmaeus is a nocturnal primate endemic to Vietnam, Laos, southern China and eastern Cambodia (Nisbett \& Ciochon, 1993; Fooden, 1996; Ratajszczak, 1998; Brandon-Jones et al., 2004). The pygmy loris differs from its congeners in morphology and genetics (Zhang et al., 1993; Wang et al., 1996; Groves, 2001, 2004; Roos, 2003, 2004; Roos et al., 2007) and in seasonal reproductive patterns and litter size (Izard \& Weisenseel, 1989; Fitch-Snyder \& Jurke, 1998). $N$. pygmaeus is categorized as Vulnerable on the IUCN Red List (Streicher et al., 2008) and all Nycticebus species are on Appendix I of CITES because of an increasing and unsustainable demand for slow lorises in international trade (Nekaris \& Nijman, 2007).

Little is known of the distribution and ecology of slow lorises, and most information has come from local informants, trade data (Nekaris \& Nijman, 2007; Starr et al., 2010) and confiscated animals (Streicher, 2003, 2004). The most intensive field studies of slow lorises have been conducted in Malaysia on the greater slow loris Nycticebus coucang (Barrett, 1984; Wiens \& Zitzmann, 1999, 2003; Wiens, 2002; Wiens et al., 2006). Some surveys of slow lorises have been conducted elsewhere (Duckworth, 1994; Tan, 1994; FitchSnyder \& Vu, 2002; Radhakrishna et al., 2006; Nekaris et al., 2008; Das et al., 2009) as well as a radio-tracking study of reintroduced animals in Vietnam (Streicher, 2004).

Pygmy lorises are rarely reported in biodiversity assessments. The reports available indicate low encounter rates (Nekaris et al., 2008). In regions where pygmy lorises occur sympatrically with the northern slow loris or the possibility exists that it does so, they are often reported together as 'slow loris', because of confusion in species identification (e.g. Walston, 2005).

Local ecological knowledge is increasingly being used by ecologists in wildlife monitoring, understanding historical and ongoing threatening processes, and collaborative action in conserving wildlife (Steinmetz et al., 2006; Brook \& McLachlan, 2008; Jones et al., 2008; Newton et al., 2008; Silvano \& Valbo-Jorgensen, 2008; Anadon et al., 2009). The knowledge of local people regarding the abundance, ecology and distribution of at least some species of local wildlife is becoming a useful component of determining a species' conservation status (Griffon \& Griffon, 2000; Steinmetz, 2004; Steinmetz et al., 2006; Newton et al., 2008). Large numbers of lorises are sold in market-places for traditional medicines (Baird, 1993; Walston, 2005; Starr et al., 2010) 
and hunters may therefore have ecological knowledge of the species.

We therefore aimed to obtain local knowledge of the distribution and ecology of, and threats to, $N$. pygmaeus and verify this information using a spotlighting survey. This knowledge may be used for developing improved management, census and conservation strategies for the species.

\section{Study area}

All data were collected in Mondulkiri Province, Cambodia, by CRS. Mondulkiri is the largest province within the distribution of the pygmy loris in Cambodia (i.e. that part of the country east of the Mekong River). It has three major protected areas, and access to sites was facilitated by conservation organizations. Spotlighting surveys and interviews were conducted in the Seima Protection Forest, Phnom Prich Wildlife Sanctuary and Mondulkiri Protected Forest (Fig. 1.). Market data were collected opportunistically from Sen Monorom Township and the neighbouring Bousra waterfall (Fig. 1). Mondulkiri has a dry season from November to April and a wet season from May to October, with mean annual rainfall of c. 2,000-2,500 $\mathrm{mm}$ and

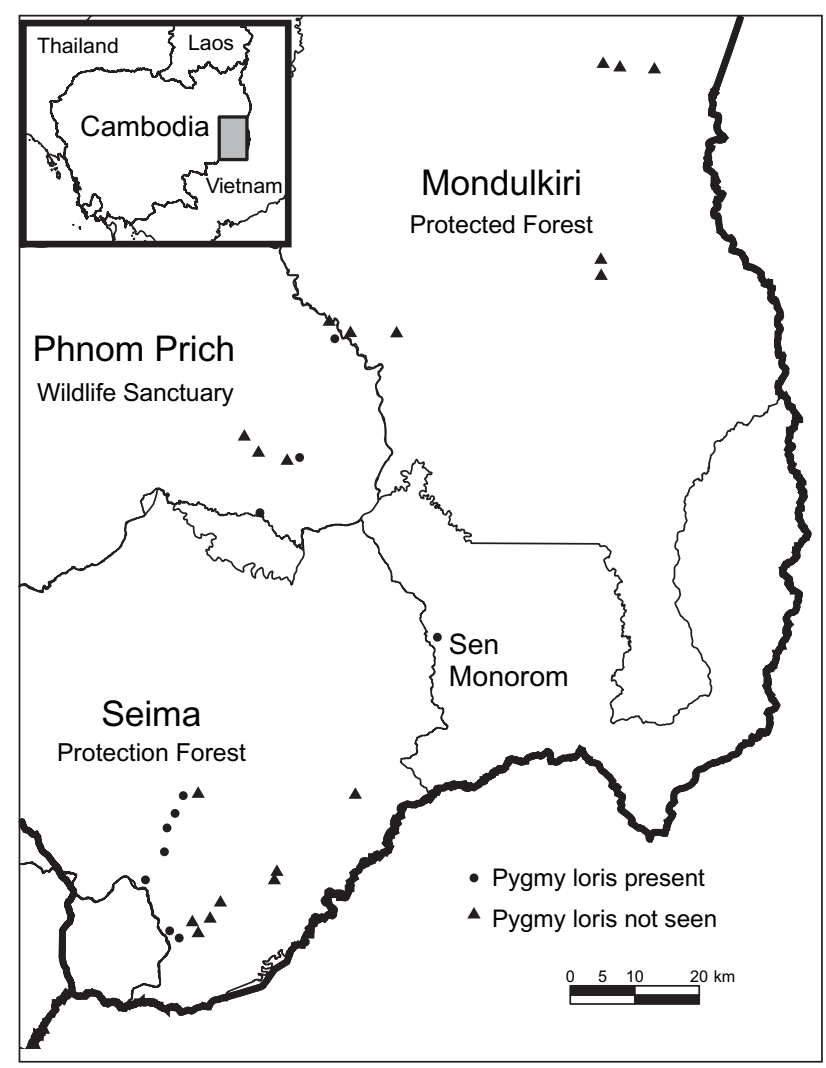

FIG. 1 Localities of the 29 spotlighting transect surveys in three protected areas in eastern Cambodia. Interviews were conducted at the closest villages to these sites. The shaded rectangle on the inset indicates the location of the main map in eastern Cambodia.
$>3,200 \mathrm{~mm}$ in more mountainous parts of the Province (Javier, 1997). Surveyed habitat types were semi-evergreen mixed deciduous and dry dipterocarp forests. Bamboo was present in all habitat types, with a cover ranging from sparse to continuous.

\section{Methods}

\section{Local ecological knowledge}

Ethnic minorities make up $70 \%$ of the population in Mondulkiri; the dominant group is the Bunong people (ADB, 2000; ICC, 2004). A principal livelihood of the Bunong is the collection of forest products, particularly liquid tree resin (Evans et al., 2003; McAndrew et al., 2003). Hunting is a traditional activity for men and is known to occur in the area (Richardson, 2003; Drury, 2005). Informants were selected from villages in close proximity to surveyed sites. Based on advice from commune leaders or park staff who came from the area, we selected informants on the basis of their reputation of having knowledge and/or experience with lorises and having lived in the study area for at least 10 years.

Semi-structured face-to-face interviews were conducted within an interview framework (Huntington, 2000). Interview questions focused on the interviewee's perceptions of how many types of loris occurred in their area and their physical characteristics (as outlined in Streicher \& Broadis, 2007). Following this, informants were shown five photographs of each species and were asked to identify if any (and how many) of the pictures resembled the lorises found in the areas described in the interview. Questions about the ecology of pygmy lorises included dietary observations, sociality, time of year young are seen and perceived habitat and vegetation preferences. Questions about threats to local loris populations covered current and historical hunting pressure, where lorises were captured, hunting methods for lorises, and habitats in which they are frequently observed. We used the following definitions of hunting pressures in assessing this during interviews : low (few lorises are hunted in the area), medium (some hunting of lorises in the area) and high (many lorises are hunted in this area).

Given that hunting and trading lorises is illegal we had to rely on a small sample of non-randomly selected exhunters and traders. The response frequency is reported as a $y / z$, where $y=$ number of informants to give the response and $z=$ total number of informants asked the question.

Interviews were conducted with 44 informants in 12 villages near the study sites, immediately before each survey (but only once at sites where we surveyed a transect more than once). All informants were fluent in Khmer. Some questions were open-ended, which allowed the informants to move into other areas of discussion. Interviews lasted 30-120 minutes. 


\section{Survey method}

During the interviews informants recommended potential survey sites for lorises. Reconnaissance survey techniques (White \& Edwards, 2000) were used for spotlighting surveys during 2006-2009. A total of 29 transects were surveyed during the 4 years (Table 1): 15 in Seima Protection Forest, 8 in Phnom Prich Wildlife Sanctuary and 6 in Mondulkiri Protected Forest. In Seima Protection Forest five of the transects (numbers 1, 2, 11-13) were surveyed more than once; all other transects were surveyed only once. Transects 1 and 2 were each surveyed six times during both the wet and the dry seasons (not during the cooler months) in 2007. Transects 1-2 and 11-13 were resurveyed twice during the cooler months (December-January) and twice in warmer months (late February-April) of the dry season in 2008-2009.

Petzl Zoom 4.5v headlamps (Petzl, Crolles, France) with a red filter were used to detect animals visually (Nekaris, 2003; Nekaris \& Jayewardene, 2004; Streicher, 2004; Nekaris et al., 2008). We did not use detection of vocalizations as part of our survey method because they were not heard and recognized as pygmy loris calls by surveyors until near the end of the study. We were unable to randomize the location of transects because of the difficult terrain. Most transects were therefore placed along preexisting paths and tracks, and those with canopy continuity across these tracks were chosen preferentially. Some new tracks were cut in Seima Protection Forest. Transects were walked slowly $\left(500-1,000 \mathrm{~m} \mathrm{~h}^{-1}\right)$ by a maximum of three people spaced at least $10 \mathrm{~m}$ apart. Once an animal was sighted, a halogen spotlight and $10 \times 40$ binoculars were used to confirm species identification. The large ears, small body size and faster locomotion of pygmy lorises compared to that of the northern slow loris made them easily distinguishable. Transect length, number of individuals sighted and height of individuals in trees were recorded. Surveys began after 18.00 and finished between 01.00 and 04.00, irrespective of moon phase. Distances to nearest settlements, main roads and rivers from each transect were later calculated using the geographical information system ArcView v. 9.1 (ESRI, Redlands, USA).

Although detection probability may have differed across sites we wished to compare our data with 37 other estimates of slow loris abundance (Nekaris et al., 2008) and therefore

TABLE 1 Schedule of surveys of transects 1-29 during 2006-2009 (see text for further details).

\begin{tabular}{llll}
\hline Year & Hot dry season & Cool dry season & Wet season \\
\hline 2006 & & $1-4$ & \\
2007 & 1,2 & & $1,2,5-11$ \\
2008 & $1,2,11-13,12-16$ & $1,2,11-13,17-24$ & \\
2009 & $1,2,11-13,25-29$ & $1,2,11-13$ & \\
\hline
\end{tabular}

used the linear encounter rate index (number of animals encountered per km; Sutherland, 2002). Slow lorises exhibit numerous characters that enhance detectability: they tend to exploit the middle to lower canopy, they are curious and do not look away when red lights are used, and they move relatively slowly compared to other nocturnal mammals. Visibility was not noticeably different between sites. Only data collected from the first survey of each transect were used for calculating encounter rate indices. Data from the five transects that were surveyed more than once were used to determine if seasonal fluctuations affected encounter rates. Student $t$-tests, correlational analyses and analysis of variance were conducted using Minitab 15 (Minitab, State College, USA) and $R$ version 2.6.2 (R Development Core Team, 2008).

\section{Results}

All 44 informants were male, aged 19-74 (19 government park protection staff, 20 ex-hunters/traders from local communities, and five taxi drivers from Bousra local market in the Provincial capital Sen Monarom). All ex-hunters and traders, taxi drivers and 10 of the park protection staff were indigenous Bunong. All informants reported they had observed, purchased, hunted, traded, sold or been involved in the confiscation of lorises within the previous 5 years.

Informants reported that lorises occurred in Seima Protection Forest and Phnom Prich Wildlife Sanctuary (100\%, 33/33). Most claimed that they were absent in many parts of Mondulkiri Protection Forest $(83 \%, 5 / 6)$, and of those informants, most believed this was because of the lack of structural complexity ('thickness') in the dry dipterocarp forest $(80 \%, 4 / 5)$, the predominant forest type in this protected area. During spotlighting surveys pygmy lorises were detected in Seima Protection Forest and Phnom Prich Wildlife Sanctuary but not in Mondulkiri Protected Forest (Table 2). A total of 26 individuals were sighted over 29 transects (total $=129.5 \mathrm{~km}$; mean transect length $=4.47$ $\mathrm{km}$; Table 2). Two types of vocalizations were heard (a short whistle was heard twice and mother-infant contact calls on four occasions). Individuals were observed 3-12 m high in the canopy. Lorises did not seem disturbed by red lights and appeared sensitive to white light, looking away when a halogen spotlight was used.

All informants believed lorises occur in thick forests that have bamboo $(100 \%, 39 / 39)$. The mean encounter rate in mixed deciduous forest $\left(\right.$ mean $=0.48 \pm \mathrm{SE} 0.17 \mathrm{~km}^{-1}$ ) was significantly $(t=1.93, \quad \mathrm{P}=0.03, \mathrm{df}=22)$ higher than the mean encounter rate in semi-evergreen forest (mean $=$ $0.28 \pm$ SE $0.07 \mathrm{~km}^{-1}$ ). Visibility across sites was exceptional compared to other slow loris sites (K.A.I. Nekaris, pers. obs.) and all lorises were observed within $12 \mathrm{~m}$ of the transect line. No lorises were encountered in dry dipterocarp forest. Mean encounter rate was significantly affected 
TABLE 2 Survey effort and results of spotlighting surveys (see text for details) for the pygmy slow loris Nycticebus pygmaeus at three sites (Fig. 1).

\begin{tabular}{llllcc}
\hline & $\begin{array}{l}\text { Total distance } \\
\text { surveyed }(\mathrm{km})\end{array}$ & $\begin{array}{l}\text { No. of } \\
\text { transects }\end{array}$ & $\begin{array}{l}\text { Total no. } \\
\text { of hours }\end{array}$ & $\begin{array}{l}\text { Mean no. of lorises } \\
\text { sighted per km SD }\end{array}$ & $\begin{array}{l}\text { Total no. of } \\
\text { lorises sighted }\end{array}$ \\
\hline Seima Protection Forest & 55.5 & 15 & 68.6 & $0.40 \pm 0.41$ & 22 \\
Phnom Prich Wildlife Sanctuary & 40.0 & 8 & 47.5 & $0.10 \pm 0.13$ & 4 \\
Mondulkiri Protected Forest & 34.0 & 6 & 37.0 & 0 & 0 \\
\hline
\end{tabular}

by the pattern of bamboo distribution $\left(\mathrm{F}_{2,21}=3.71, \mathrm{P}=\right.$ 0.04). No pairwise comparisons were significant, possibly because of the small sample size; the mean encounter rates were $0.0 \mathrm{~km}^{-1}$ in transects with no bamboo, $0.13 \mathrm{~km}^{-1}$ (95\% confidence interval $-0.37-0.63 \mathrm{~km}^{-1}$ ) in transects with continuous bamboo distribution and $0.46 \mathrm{~km}^{-1}$ (-0.04$0.96 \mathrm{~km}^{-1}$ ) in transects with patches of bamboo.

On Transects 1-2 surveyed across the wet and dry seasons in 2007 encounter rates remained relatively consistent over time (Transect 1: mean $=0.35 \pm$ SE $0.06 \mathrm{~km}^{-1}$; Transect 2: mean $=0.80 \pm \mathrm{SE} 0.06 \mathrm{~km}^{-1}$ ). On Transects 1113, where there were high encounter rates in early 2008, when they were first sampled, no animals were found in either season when they were later re-surveyed. Local people reported high hunting pressures of lorises and other nocturnal mammals in two of these sites during the wet season in 2008. At the site of the third transect a gold mine development was underway when we repeated the survey in 2008. Gunshots and chainsaws were frequently heard across sites, and local people with spotlights were seen walking in the forests at night. The latter activity was reportedly associated with hunting nocturnal mammals.

All informants described two types of loris in their local area $(100 \%, 44 / 44)$, characterized as the 'large grey loris' and the 'small red loris'. Informants all identified the small red loris in photographs as the pygmy loris $(100 \%, 44 / 44)$ but fewer identified the northern slow loris $(27.3 \%, 12 / 44)$ as the large grey loris, with the remaining informants believing it was either a pygmy loris $(18.2 \%, 8 / 44)$ or a type that was not present in the area $(54.5 \%, 24 / 44)$.

Informants believed lorises live in pairs $(56 \%, 22 / 39)$, are solitary $(13 \%, 5 / 39)$ or did not know $(31 \%, 12 / 39)$. On four occasions during our surveys we observed lorises in close proximity to each another $(<20 \mathrm{~m})$. Only two ex-hunters $(4.5 \%, 2 / 44)$ had seen young pygmy loris, and reported sightings in April and May. In April 2008 we observed two parked infants side by side that were c. 3 months old.

Informants reported that the diet of lorises consists of termites $(36 \%, 14 / 39)$, tree parts (leaves/bark/buds; $31 \%$, $12 / 39)$, fruit $(26 \%, 10 / 39)$, bamboo $(15 \%, 6 / 39)$ and fungi $(2 \%, 1 / 39)$. We made 16 feeding observations during our surveys: four on ripe fruits of the vine Salacia chinensis, six of tree exudates (gums), three of arthropods, and three of lorises licking and breaking open dead bamboo culms. Later, we opened the culms $(n=4)$ and found they were full of termites and insects. Lichen was also observed on the outside of bamboo culms and may be a food item for pygmy lorises.

In Seima Protection Forest most informants reported current hunting pressures of lorises as medium (30.8\%, $4 / 14)$ and high $(53.8 \%, 7 / 13)$. Park staff, however, claimed hunting was low in the area $(15.4 \%, 2 / 13)$ but were likely to have a vested interest in reporting low hunting pressures. In Phnom Prich Wildlife Sanctuary loris hunting pressures were also reported as medium $(50 \%, 10 / 20)$ and high $(40 \%$, $8 / 20$ ). In Mondulkiri Protection Forest loris hunting was recorded as low to absent $(100 \%, 5 / 5)$ because lorises were not thought to occur in this area. All informants with experience of hunting or trading reported a reduction in loris numbers $(100 \%, 20 / 20)$ and thought this was a result of high hunting pressure $(100 \%, 20 / 20)$. Across the sites, 2001-2002 was reported as a period with the largest demand and offtake of lorises, with many traders visiting the area $(74 \%, 29 / 39)$. One informant claimed to trade $c$. 1,200 lorises year ${ }^{-1}$ in 2001 and 2002 in Phnom Prich Wildlife Sanctuary. He was only one of three professional wildlife traders in his village (which had 108 families). One informant reported large harvests from near his village in 2007 and another suggested the highest hunting pressure he had known was in 2008. Although in most sites hunting was reported to have eased since 2001-2002, three informants reported that population expiration had already occurred in some sites $(6.8 \%, 3 / 44)$. Some ex-hunters $(30 \%, 6 / 20)$ suggested that this 2001-2002 period also coincided with access in local markets to improved batteries for spotlights from Thailand and Vietnam, facilitating longer hunting trips deeper into the forest.

When asked to rank the severity of the decline of local loris populations it was most often reported as high (Seima Protection Forest, 69.2\%, 9/13; Phnom Prich Wildlife Sanctuary, 50\%, 10/20). Pygmy lorises were reported to be captured as a non-target species on hunting trips by nearly all informants who were ex-hunters or traders $(90 \%, 18 / 20)$ and only two believed hunters specifically target lorises $(10 \%, 2 / 20)$. Despite not being a target species, if a loris is encountered hunters will always try to capture it $(100 \%, 20 / 20)$. Lorises are reported to 
be located with a spotlight and either hand captured, shaken off the tree or shot with a slingshot.

Ex hunters and traders reported that they often hunted lorises during the wet season $(70 \%, 14 / 20)$ or captured them after the forest had been burnt to increase access to resin trees in the dry season $(35 \%, 7 / 20)$. In Phnom Prich Wildlife Sanctuary many informants $(50 \%, 10 / 20)$ believed it was a bad omen to see a large grey loris at the beginning of a hunting trip because it would hamper their offtake of other wildlife.

Encounter rates of pygmy lorises were not significantly correlated with distance to main roads $(r=-0.21, \mathrm{P}=-0.33$, $\mathrm{df}=22)$, villages $(r=-0.41, \mathrm{P}=0.68, \mathrm{df}=22)$ or rivers $(r=0.25, \mathrm{P}=0.24, \mathrm{df}=22)$. Pygmy lorises were reported by some informants $(31 \%, 4 / 13)$ to be a pest in cashew plantations in Seima Protection Forest where they were thought to consume or to drink liquid from the fruits. Pygmy lorises seen in crops were captured and killed for traditional medicines.

The preparation and open sale of pygmy lorises for traditional medicine was opportunistically observed in three villages in the Province. One major market-place in Mondulkiri that sold lorises was at a popular tourist destination, Bousra Waterfall. CRS observed 30 dried pygmy lorises in a single day on three stalls. Market informants reported that wildlife was primarily sold on weekends and targeted Cambodian tourists $(100 \%, 5 / 5)$. Dried pygmy lorises were often seen during visits to villages.

\section{Discussion}

Our field data, supplemented with the local ecological knowledge that we collected in the interviews, indicated severe declines in the populations of pygmy lorises surveyed. These declines are a result of persistent, extensive harvesting of pygmy lorises for traditional medicines and are exacerbated by increased access to the forest, access to improved equipment that facilitates night hunting, and limited law enforcement. Absence of this species from the relatively abundant dry dipterocarp forest further decreases its area of occupancy in Cambodia. Local people have a good knowledge of the behaviour and ecology of pygmy lorises and hunters seem to know the species' favoured habitats and the times of year at which the animals can most easily be caught.

Interview data, declining encounter rates from repeated spotlighting surveys and observations of dried animals for sale all indicated high hunting pressure. The encounter rates of $0.10-0.40 \mathrm{~km}^{-1}$ are similar to those from other studies, ranging from $0.02 \mathrm{~km}^{-1}$ for the Bornean slow loris Nycticebus menagensis to $0.80 \mathrm{~km}^{-1}$ for the greater slow loris N. coucang (Nekaris et al., 2008). Although low abundance may characterize the genus, the encounter rates in our study were highest on the first survey along three of the transects surveyed more than once but were zero in late 2008 and 2009. These transects were located further from park protection base camps than the other two transects surveyed multiple times. Local informants reported that many hunters entered the area of these transects during the wet season of 2008. At the site where a gold mine is being developed the workers were living on site within the protected area. We resurveyed transects at this site in warmer months to ensure that the zero encounter rate was not related to temperature.

Although encounter rates in repeated surveys on two of the transects were relatively consistent across the wet and dry seasons in Seima Protection Forest we do not recommend conducting surveys and monitoring pygmy lorises during cooler months. In a separate long-term study of radio-collared lorises, individuals remained inactive for long periods on all-night follows during December and January, when temperatures reached as low as 13.7 degrees (C. Starr, pers. obs).

Prior to this study the pygmy loris was reported to occur in primary rainforest, secondary and degraded habitats, patches of bamboo in Vietnam (Dang, 1998; Ratajszczak, 1998; Fitch-Snyder \& Vu, 2002), and evergreen and semievergreen forest in Laos (Duckworth, 1994). Significantly higher encounter rates in mixed deciduous forests in our study indicate that this is a preferred habitat type for pygmy lorises in these sites. We did not encounter lorises, or receive reports of their occurrence, in dry dipterocarp forests in eastern Cambodia. As current Red List assessments for the pygmy loris are based on habitat availability alone, exclusion of this habitat from their area of occupancy could have a major impact on their conservation status. If evergreen forest is used by the species in Cambodia then this may provide an important habitat for its conservation, as access for hunting appears to be restricted because of fear of elephants by local hunters.

The reported use of bamboo by lorises for foraging and locomotion, combined with higher encounter rates in areas with bamboo patches, indicate that this is an important resource for the species. Such a vegetation mosaic may provide a more stable supply of food for pygmy lorises (e.g. invertebrates from bamboo patches and fruits, gums and exudates from trees). Bamboo is collected and used by local people in Mondulkiri Province (Evans et al., 2003) and local people suggested we search for lorises in areas with a high density of bamboo. The ease of capturing lorises, both sleeping and active, in bamboo stands is another threat to this species.

In addition to knowledge of loris habitat, local people identified numerous aspects of loris behaviour that were reaffirmed by our field data. Pygmy lorises were not always solitary, they have small young in April and they emit several types of calls. Local people also reported that pygmy lorises are a pest in cashew plantations (see also Scally et al., 
2006). In the northernmost part of its distribution range in Vietnam the species appeared to have been locally extirpated based on the belief that it is a crop pest (Streicher, 2004); however, pygmy lorises may be gouging cashew trees or hunting insects. If lorises are consuming invertebrate pests of cashew this knowledge may be useful as a tool to curtail hunting of them in plantations.

Informants separated lorises into two locally distinct types by colour (red or grey) and body size (big or small) and this could imply presence of the northern slow loris in the area. However, no confirmed sightings of northern slow lorises have been made east of the Mekong River in Cambodia. Streicher $(2003,2004)$ identified seasonal variation in pelage of pygmy lorises in Vietnam and this may have lead to a local folk taxonomy.

Informants provided considerable information about the ecology of, and threats to, pygmy lorises. Although our interview data were qualitative in nature, recent studies have identified the potential for using local ecological knowledge for collecting quantitative abundance indices of wildlife. Anadon et al. (2009) found that using such knowledge was 100 times cheaper than linear transect surveys, provided data for a larger spatial area, and abundance estimates and trends were similar to those obtained using distance sampling methods. Because of the difficulty of surveying slow lorises in the field and the knowledge people have of these animals, local ecological knowledge may be a useful supplement to field surveys in the region.

Both interview and field data in our study identified the hunting of lorises as a non-target species. Target species have some protection from negative feedback: as numbers decrease they are less profitable to hunt. Hunting of nontarget species is not, however, affected by their abundance (Sutherland \& Gill, 2001), and non-target species are likely to continue to be opportunistically collected by hunters even if their numbers are decreasing. While lorises were probably used historically for traditional medicine (Nekaris \& Bearder, 2007), the advent of modern spotlighting equipment facilitates hunting.

The common availability of lorises in markets in Cambodia is well-documented (Baird, 1993; Broad, 1994; Martin \& Phipps, 1996; Stich \& Krüger, 2002; Starr et al., 2010). The first known large scale wildlife markets in Cambodia emerged in Phnom Penh and Sen Monorom in 1985 and with this came sophisticated networks of hunters, middlemen and traders (Walston et al., 2001). Informants reported that large scale commercial harvesting of lorises only began in the 1990s, with access to improved batteries for spotlights and with traders arriving the area. The reported intensive hunting pressure and subsequent population declines are matters that need to be immediately addressed in the protected areas. We recommend that a full conservation status assessment of the species across eastern Cambodia be conducted, using village interviews and field surveys.
Wildlife monitoring programmes are in place in the protected areas in the Mondulkiri Province, and efforts to conserve large iconic species appear to be successful (Pollard et al., 2007). Similar monitoring programmes should be extended, however, to lower profile species such as the pygmy loris. Our data suggest that priority conservation efforts should be effective law enforcement to curb hunting in semi-evergreen and mixed deciduous forests in these protected areas and the trade and sale of pygmy lorises in the province.

The lack of ecological information on small nocturnal mammals is due largely to the lack of funds available for studying this group. When such studies are conducted, they often reveal low abundance, previously unknown threats, and new species. We urge NGOs to consider channelling funds towards monitoring of nocturnal mammals and to recognize the conservation needs of these non-charismatic species.

\section{Acknowledgements}

We are grateful to staff from the Forestry Administration, the Ministry of Environment, and the Wildlife Conservation Society, WWF and Fauna \& Flora International Cambodia programmes for their advice and support. Will Duckworth provided feedback on the text. This research would not have been possible without the invaluable help provided by the local people both in the field and in sharing their knowledge. Animal (SAS/696/07/PhD) and Human (2006000222) ethics were approved by the University of Queensland for this study.

\section{References}

ADB (Asian Development Bank) (2000) Health and Education Needs of Ethnic Minorities in the Greater Mekong Sub-Region. Asian Development Bank, Phnom Penh, Cambodia.

Anadon, J.D., Gimenez, A., Ballestar, R. \& Perez, I. (2009) Evaluation of local ecological knowledge as a method for collecting extensive data on animal abundance. Conservation Biology, 23, 617-625.

B AIRD, I. (1993) Logging and lorises in Cambodia. IPPL News, 20, $19-20$.

B ARRETT, E. (1984) The ecology of some nocturnal, arboreal mammals in the rainforests of peninsular Malaysia. $\mathrm{PhD}$ thesis, University of Cambridge, Cambridge, UK.

Brandon-Jones, D., Eudey, A.A., Geissmann, T., Groves, C.P., Melnick, D.J., Morales, J.C., Shekelle, M. et al. (2004) Asian primate classification. International Journal of Primatology, 25, 97-164.

Broad, S. (1994) Trip report: Phnom Penh, Cambodia. Unpublished Report. TRAFFIC South-east Asia, Petaling Jaya, Malaysia.

BROOK, R.K. \& MCLACHLAN, S.M. (2008) Trends and prospects for local knowledge in ecological and conservation research and monitoring. Biodiversity and Conservation, 17, 3501-3512.

DANG, H.H. (1998) Ecology, biology and conservation status of prosimian species in Vietnam. Folia Primatologica, 69, 101-108. 
Das, N., Biswas, J., Das, J., Ray, P.C., Sangma, A. \& Bhattacharjee, P.C. (2009) Status of Bengal slow loris Nycticebus bengalensis (Primates: Lorisidae) in Gibbon Wildlife Sanctuary, Assam, India. Journal of Threatened Taxa, 1, 558-561.

DRURY, R. (2005) Wildlife use and trade in Seima Biodiversity Conservation Area, Mondulkiri Province, Cambodia. MSc thesis, University of London, London, UK.

Duckworth, J.W. (1994) Field sightings of the pygmy Loris, Nycticebus pygmaeus in Laos. Folia Primatologica, 63, 99-101.

Evans, T.D., Piseth, H., Phaktra, P. \& Mary, H. (2003) A Study of Resin-Tapping and Livelihoods in Southern Mondulkiri, Cambodia, with Implications for Conservation and Forest Management. Wildlife Conservation Society-Cambodia Program, Phnom Penh, Cambodia.

Fitch-SNyder, H. \& Jurke, M. (1998) Reproductive patterns in pygmy lorises (Nycticebus pygmaeus): behavioural and physiological correlates of gonadal activity. Zoo Biology, 22, 15-32.

Fitch-SNyder, H. \& Vu, N.T. (2002) A preliminary survey of lorises (Nycticebus spp.) in northern Vietnam. Asian Primates, A Newsletter of the IUCN/SSC Primate Specialist Group, 8, 1-3.

Fooden, J. (1996) Zoogeography of Vietnamese Primates. International Journal of Primatology, 17, 845-899.

Griffon, P.B. \& Griffon, M.B. (2000) Agta hunting and sustainability of resource use in north-eastern Luzon, Philippines. In Hunting for Sustainability in Tropical Forests (eds J.G. Robinson \& E.L. Bennett), pp. 325-335. Columbia University Press, New York, USA.

Groves, C.P. (2001) Primate Taxonomy. Smithsonian Institute Press, Washington, DC, USA.

Groves, C.P. (2004) Taxonomy and biogeography of primates in Vietnam and neighbouring regions. In Conservation of Primates in Vietnam (eds T. Nadler, U. Streicher \& T.L. Ha), pp. 15-22. Haki Press, Hanoi, Vietnam.

Huntington, H.P. (2000) Using traditional ecological knowledge in science: methods and applications. Ecological Applications, 10, $1270-1274$.

ICC (International Cooperation Cambodia) (2004) A Livelihood and Gender Study of Three Bunong (Phnong) Kroms, Mondulkiri, NE Cambodia. International Cooperation Cambodia, Phnom Penh, Cambodia.

IUCN (2010) IUCN Red List of Threatened Species v. 2010.2. Http:// www.iucnredlist.org [accessed 12 July 2010].

Izard, M.K. \& Weisenseel, K. (1989) Comparative reproduction of the Lorisidae. American Journal of Primatology, 18, 140.

JAvier, E.L. (1997) Rice systems and varieties. In Rice Production in Cambodia (ed. H.J. Nesbitt), 39-81. International Rice Research Institute, Manila, Philippines.

Jones, J.P.G., Andriamarovololona, M.M., Hockley, N., Gibbons, J.M. \& Milner-Gulland, E.J. (2008) Testing the use of interviews as a tool for monitoring trends in the harvesting of wild species. Journal of Animal Ecology, 45, 1205-1212.

Martin, E. \& Phipps, M. (1996) A review of wild animal trade in Cambodia. TRAFFIC Bulletin, 16, 45-60.

McAndrew, J.P., Mam, S., Hong, K. \& Ly, B. (2003) Indigenous Adaptation to a Decline in Natural Resources. The Experience of Two Phnong Communes in North-east Cambodia. CIDSE, Phnom Penh, Cambodia.

NeKaris, K.A.I. (2003) Spacing system of the Mysore slender loris (Loris lydekkerianus lydekkerianus). American Journal of Physiological Anthropology, 121, 86-96.

NeKARIS, K.A.I. \& BEARDER, S.K. (2007) The strepsirrhine primates of Asia and Mainland Africa: diversity shrouded in darkness. In Primates in Perspective (eds C. Campbell, A. Fuentes, K.
MacKinnon, M. Panger \& S.K. Bearder), pp. 24-45. Oxford University Press, Oxford, UK.

Nekaris, K.A.I., Blackham, G.V. \& Nijman, V. (2008) Conservation implications of low encounter rates of five nocturnal primate species (Nycticebus spp.) in Asia. Biodiversity and Conservation, 17, 733-747.

Nekaris, K.A.I. \& Jayewardene, J. (2004) Survey of the slender loris (Primates, Lorisidae Gray, 1821: Loris tardigradus Linnaeus, 1758 and Loris lydekkerianus cabrera, 1908) in Sri Lanka. Journal of Zoology (London), 262, 327-338.

NeKaris, K.A.I. \& NiJMAn, V. (2007) CITES proposal highlights rarity of Asian nocturnal primates (Lorisidae: Nycticebus). Folia Primatologica, 78, 211-214.

Newton, P., Nguyen Van, T., Robertson, S. \& Bell, D. (2008) Pangolins in peril: using local hunters' knowledge to conserve elusive species in Vietnam. Endangered Species Research, 6, 41-53.

Nisbett, R.A. \& Ciochon, R.L. (1993) Primates in North Vietnam: a review of the ecology and conservation status of extant species, with a note on Pleistocene localities. International Journal of Primatology, 14, 765-795.

Pollard, E.H.B., Clements, T., Hor, N.M., Ko, S. \& Rawson, B. (2007) Status and Conservation of Globally Threatened Primates in the Seima Biodiversity Conservation Area, Cambodia. Wildlife Conservation Society and Forestry Administration, Phnom Penh, Cambodia.

R Development Core Team (2008) R: A Language and Environment for Statistical Computing. R Foundation for Statistical Computing, Vienna, Austria. Http://www.R-project.org [accessed 12 July 2010].

Radhakrishna, S., Goswami, A.B. \& Sinha, A. (2006) Distribution and conservation of Nycticebus bengalensis in north-eastern India. International Journal of Primatology, 27, 971-982.

Ratajszczak, R. (1998) Taxonomy, distribution and status of the lesser slow loris Nycticebus pygmaeus and their implications for captive management. Folia Primatologica, 69, 171-174.

Richardson, M. (2003) Sustainable rural livelihoods and wildlife: the role of wildlife and fish in the subsistence livelihoods of three indigenous Phnong communities in southern Mondulkiri Province, Cambodia. MSc thesis, University of London, London, UK.

Roos, C. (2003) Molekulare Phylogenie der Halbaffen, Schlankaffen, und Gibbons. PhD thesis. Technischen Universität, Munich, Germany.

Roos, C. (2004) Molecular evolution and systematics of Vietnamese primates. In Conservation of Primates in Vietnam (eds T. Nadler, U. Streicher \& T.L. Ha), International Cooperation Cambodia. Haki Press, Hanoi, Vietnam.

Roos, C., Thanh, V.N., Nadler, W.L. \& Nadler, T. (2007) Molecular systematics of Indochinese primates. Vietnamese Journal of Primatology, 1, 41-53.

Scally, K., Evans, T.D. \& Meng Hor, N. (2006) Human-Wildife Conflict in and around Seima Biodiversity Conservation Area, Mondulkiri and Kratie Provinces, Cambodia. Wildlife Conservation Society-Cambodia Program, Phnom Penh, Cambodia.

Silvano, R.A.M. \& Valbo-Jorgensen, J. (2008) Beyond fishermen's tales: contributions of fishers' local ecological knowledge to fish ecology and fisheries management. Environment Development and Sustainability, 10, 657-675.

Starr, C.R., Nekaris, K.A.I., Streicher, U. \& Leung, L.K.-P. (2010) Traditional use of slow lorises Nycticebus bengalensis and N. pygmaeus in Cambodia: an impediment to their conservation. Endangered Species Research, 12, 17-23.

SteinmetZ, R. (2004) Gaur (Bos gaurus) and Banteng (B. javanicus) in the lowland forest mosaic of Xe Pian Protected Area, Lao PDR: abundance, habitat use, and conservation. Mammalia, 68, $141-157$. 
Steinmetz, R., Chutipong, W. \& Seunturien, N. (2006) Collaborating to conserve large mammals in South-east Asia. Conservation Biology, 20, 1391-1401.

StiCh, I. \& KrÜGER, K.-O. (2002) Artenschutz in Kambodscha. ZGAP Mitteilungen, 18. Jahrgang, 2, 7-9.

Streicher, U. (2003) Seasonal variation in fur colouring and markings in the Pygmy loris (Nycticebus pygmaeus) and its taxonomic significance. Zoologische Garten, 73, 368-373.

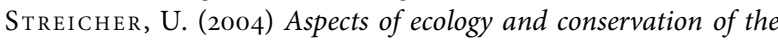
pygmy loris Nycticebus pygmaeus in Vietnam. PhD thesis, Ludwig-Maximilians Universitaet, Munich, Germany.

STREICHER, U. \& BRoAdis, N. (2007) Loris Species of Cambodia and Vietnam. Wildlife Alliance, Phnom Penh, Cambodia.

Streicher, U., Ngoc Thanh, V., Nadler, T., Timmins, R.J. \& NEKARIS, A. (2008) Nycticebus pygmaeus. In IUCN Red List of Threatened Species v. 2010.2. Http://www.iucnredlist.org [accessed 12 July 2010].

Sutherland, W.J. (2002) Mammals. In Ecological Census Techniques (ed. W.J. Sutherland), pp. 260-278. Cambridge University Press, Cambridge, UK.

Sutherland, W.J. \& Gill, J.A. (2001) The role of behaviour in studying sustainable exploitation. In Conservation of Exploited Species (eds J.D. Reynolds, G.M. Mace, K.H. Redford \& G. Robinson), pp. 259-280. Cambridge University Press, Cambridge, UK.

Walston, J., Davidson, P. \& Soriyun, M. (2001) A Wildlife Survey of Southern Mondulkiri Province, Cambodia. Wildlife Conservation Society-Cambodia Program, Phnom Penh, Cambodia.

Walston, N. (2005) An Overview of the Use of Cambodia's Plants and Animals in Traditional Medicine Systems. TRAFFIC Southeast Asia-Indochina, Phnom Penh, Cambodia.

Wang, W., Su, B., Lan, H., LiU, R., Zhu, C., Nie, W. et al. (1996) Interspecific differentiation of the slow lorises (Genus Nycticebus) inferred from ribosomal DNA restriction maps. Zoological Research, 17, 89-93.

White, L. \& Edwards, A. (2000) Methods for assessing the status of animal populations. In Conservation Research in the African
Rain Forests: A Technical Handbook (eds L. White \& A. Edwards), pp. 91-201. Wildlife Conservation Society, New York, USA.

WiENs, F. (2002) Behaviour and ecology of wild slow lorises (Nycticebus coucang): social organisation, infant care system, and diet. PhD thesis. Bayreuth University, Bayreuth, Germany.

Wiens, F. \& Zitzmann, A. (1999) Predation on a wild slow loris (Nycticebus coucang) by a reticulated python (Python reticulatus). Folia Primatologica, 70, 362-364.

Wiens, F. \& Zitzmann, A. (2003) Social structure of the solitary slow loris Nycticebus coucang (Lorisidae). Journal of Zoology (London), 261, 35-46.

Wiens, F., Zitzmann, A. \& Hussein, N.A. (2006) Fast food for slow lorises: is low metabolism related to secondary compounds in high-energy plant diet? Journal of Mammalogy, 87, 790-798.

Zhang, Y., Chen, Z. \& Shi, L. (1993) Phylogeny of the slow lorises (Genus Nycticebus): an approach using mitochondrial DNA restriction enzyme analysis. International Journal of Primatology, $14,167-175$.

\section{Biographical sketches}

CARLY STARR has conducted research on the conservation and ecology of slow lorises in Cambodia with emphasis on the pygmy slow loris in eastern Cambodia. She has worked in Cambodia since 2004 with both vertebrate pests and small to medium sized mammals. ANNA NEKARIS has studied Asian mammals in the wild and in captivity for more than 15 years. She has conducted field studies of all currently recognized taxa of slow and slender lorises, and has initiated conservation awareness and capacity building projects in numerous range countries. ULRIKE STREICHER is a veterinarian specializing in Asian wildlife since 1997 , with a special focus on primates, particular rescue, rehabilitation, translocation, reintroduction and monitoring. She started working with lorises in 1998, in particular with the pygmy loris. LUKE LEUNG is a field ecologist with an interest in the management of wildlife populations, especially with rare and threatened species but also vertebrate pests. 